
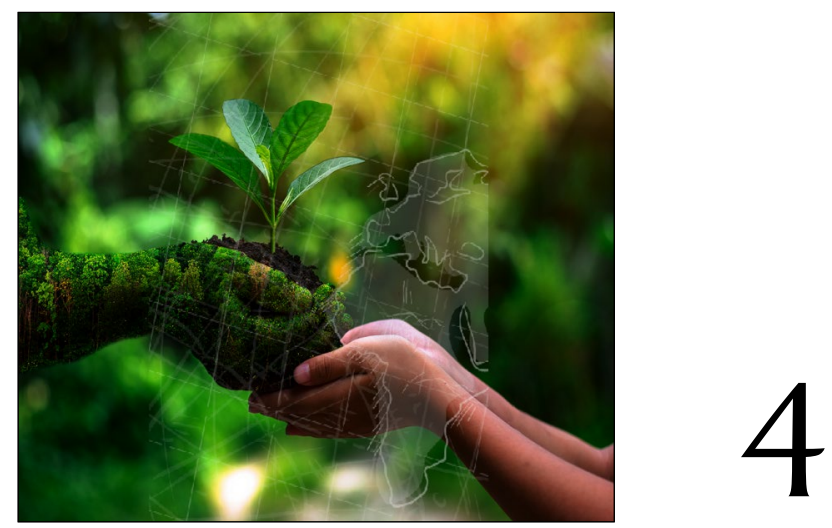

\title{
INCLUSIVE AND SUSTAINABLE INDUSTRIAL DEVELOPMENT FOR AFRICA
}

\author{
Desta Mebratu
}

\section{Introduction}

The first industrial revolution, which started in the United Kingdom in the eighteenth century, heralded the beginning of the second major social transformation in human history. The introduction of coal as the primary energy source for socio-economic activity and steam power as the primary driver of manufacturing processes were the two significant features that characterised the period. Over the subsequent two and a half centuries, the industrial revolution has gone through different stages of development that fundamentally reshaped the national and global economy. As a result of these developments, global gross domestic product output grew by 23-fold from 1900 to 2010 (International Resource Panel [IRP], 2014) leading to significant improvement of wellbeing, particularly in developed countries. However, this economic growth was registered at a considerable price on the natural system which resulted in a ten-fold increase in extraction of natural resources, a 34 fold increase in extraction of construction 
minerals and a 27-fold increase in extraction of industrial ores and minerals (IRP, 2014). Besides the destruction of the natural habitat, the unsustainable exploitation and use of fossil fuels resulted in the systemic deposition of greenhouse gases leading to climate change, which is the most complex challenge faced by humanity.

African countries have been aspiring to industrialise their economies since their early years of liberation. By the mid-1960s, many African governments conceived bolder plans and programmes on industrialisation. This was given a continental scope with the adoption of the Lagos Plan of Action in April 1980 for the collective industrialisation of Africa. Since the 1970s, more specifically as a follow-up to the Lagos Plan of Action, many African countries embarked upon ambitious industrial development programmes that were primarily driven by massive public investment in building physical infrastructure. Nevertheless, except for a couple of North African countries and South Africa, most of them failed to achieve their stated goals. As a result, for decades Africa's share of global manufacturing output remained minuscule compared to other regions. Over the last decade, Africa has seen a renewed interest in industrialisation from within and from the outside world. The United Nations Economic Commission for Africa (UNECA) noted that industrialisation is an imperative for Africa to meet the objectives of Agenda 2063 within a global economy constrained by climate change and driven by competitive supply chains and complex supply and demand dynamics (UNECA, 2015).

Industrialisation in Africa, however, does not necessarily need to follow the same path of polluting and inefficient industrialisation process that had been followed by countries in other regions. Given the complex socio-economic and socioecological challenges faced by African countries and the emerging trends of industrialisation, it is not a matter of choice for African countries but to adopt a new path of industrialisation that creates jobs and livelihood to its people, particularly its large young population, while at the same time maintaining the sustainability and integrity of its natural ecosystems.

The objective of this chapter is to provide an overall framework for an industrial development in Africa that is inclusive, low carbon and resource efficient. To this end, the first section looks at the various stages of industrialisation with a particular focus on emerging industrialisations trends and drivers. This is followed with a section on status and trends of industrialisation in Africa with a focus on the lessons that are drawn from past experiences. The final section presents a generic framework for inclusive and sustainable industrialisation in Africa. 


\section{Drivers of industrialisation and its impact}

There is a vast volume of literature on various models of industrialisation that have been followed by many countries over the last couple of centuries. While some useful lessons could be drawn from the experiences of these countries, neither the European model nor the 'so-much-talked-about' Asian models of industrialisation are appropriate for Africa for the following two main reasons. Firstly, attempting to industrialise through the conventional model of industrialisation is neither feasible nor sustainable within the available regenerative and assimilative capacity of the planetary ecosystem, which is already constrained. The Global Resource Outlook produced by the IRP (2019) stated that the decoupling of natural resource use and environmental impacts from economic activity and human wellbeing is an essential element in the transition to a sustainable future. Secondly, the industrialisation of the twenty-first century is fundamentally different from previous industrialisation paths, both in terms of its technological drivers and the expected socio-economic outcome and impacts. In this context, it is vital that African countries understand the fundamental technological drivers and resource constraints of industrialisation in the twenty-first century.

The twentieth century was a century of unprecedented economic growth driven by a faster pace of industrialisation and globalisation. However, it was also a century that saw exponential growth in the volume of resources extracted from the natural environment and the related environmental degradation. The need for a fundamental transformation in our production and consumption structure is already agreed globally through the Paris Declaration on Climate Change and the Agenda 2030 on Sustainable Development Goals (SDGs). While the industrialisation process may have a different scope and context from one country to another, technological innovation has been one of the common drivers of industrialisation. Another critical feature of industrialisation that took a global dimension has been the adverse impact of industrial activities on the natural environment and the subsequent global reaction to it. This subsection highlights the key features of technological innovations that have determined the path and pace of industrialisation over the years. It also reviews the dominant thinking that emerged on how to address the adverse impact of industrialisation on the natural environment.

\section{Technological innovation as a driver of industrialisation}

From a transformative development perspective, innovation holds a central place in any form of social transformation in human history. Besides the production of various hunting tools, the creation of fire had been the first and, perhaps, the most 
significant innovation that defined the fundamental distinction between the homosapiens and its closely related animals. This was followed by the domestication and use of the bio-energy of animals for productive activities, including for farming and mobility, together with the production of various types of farming tools, which led to permanent settlement and expansion of agricultural farming. The process of technological innovation has been the most potent driver of industrialisation and wealth creation since the onset of the industrial revolution. Schwab (2018) identified the following four stages of the industrial revolution in relation to technological innovation:

First industrial revolution: This stage represents the period from the mideighteenth century to the mid-nineteenth century which transformed every sector of production from machine tools to steelmanufacturing, the steam engine and railways. New technologies led to shifts in cooperation and competition that, in turn, created entirely new systems of value production, exchange and distribution, and upended sectors from agriculture to manufacturing, from communication to transport.

Second industrial revolution: A new wave of interrelated technologies that came from 1870-1930 compounded the growth and opportunity that came from the first industrial revolution. This included new communication technologies driven by the transformative power of electricity, transportation technologies driven by the internal combustion engine, the ability to produce diverse materials from plastics to fertilisers driven by the development in chemical processes.

Third industrial revolution: The revolutionary breakthrough that occurred around the middle of the twentieth century in information theory and digital computing is at the heart of the third industrial revolution. The ability to store, process and transmit information in digital form reformatted almost every industry and dramatically changed the working and social lives of billions of people.

Fourth industrial revolution: Emerging technologies that drive the fourth industrial revolution build upon the knowledge and systems of previous industrial revolutions, in particular, the digital capabilities of the third industrial revolution. These emerging technologies include artificial intelligence (AI) and robotics, additive manufacturing, new materials and energy technologies, biotechnologies, and virtual and augmented reality.

While Schwab looks at the different stages of the industrial revolution from the perspective of how productive economies are structured and organised, Jeremy Rifkin looks at how energy and communication technologies drove economic transitions. Rifkin (2011) argues that significant economic transformations in 
history occur when new communication technology converges with new energy systems. He further notes that the new form of communications became the medium for organising and managing the more complex civilisations made possible by the new sources of energy. Based on this, Rifkin identifies the following three stages of the industrial revolution (Rifkin, 2011):

First industrial revolution: The introduction of steam-powered technology into printing transformed the medium into the primary communications tool to manage the first industrial revolution. The advent of public schooling between the 1830s and 1890s created a print-literate workforce to organise the complex operations of a coal-powered, steam-driven rail and factory economy.

Second industrial revolution: The convergence of electrical communication with the oil-powered mineral combustion engine during the first decade of the twentieth century gave rise to the second industrial revolution. The electrification of factories ushered in the era of mass-produced goods, the most important being the automobile.

Third industrial revolution: The conjoining of internet communication technology and renewable energy represents the latest convergence of communication technology and energy systems, thereby laying the foundation for the third industrial revolution. This convergence will enable hundreds of millions of human beings to generate their own green energy from the roof of their homes, offices and factories and share it across intelligent distributed electricity networks.

As a result of the significant economic transformation caused by the different stages of the industrial revolution, average real income per person in industrialised economies has increased around 2900 percent since the industrial revolution, while life expectancy at birth has more than doubled in almost every country (Schwab, 2018). Rifkin (2011) noted that the third industrial revolution would have as significant an impact in the twenty-first century as the first industrial revolution had in the nineteenth century and the second industrial revolution in the twentieth century.

Rifkin (2011) also underlined that the traditional top-down organisation of society that characterised much of the economic, social and political life of the fossil-fuel-based industrial revolution is giving way to a distributed and collaborative relationship in the emerging green industrial era. While Schwab and Rifkin may seem to start with different premises, both of them come to similar conclusions on the vital role of innovation in industrialisation and the possible path of industrialisation in the twenty-first century. Perez (2010) noted that the Information and communications technology (ICT)-led shift in the development 
paradigm needs to be production-centred, pro-development with dynamic locally differentiated markets that enhance national identities and reach towards optimum worldwide welfare. This is all good news from a developing country context as many developing countries are well-positioned to become nodal centres of this new global (re-)industrialisation which drives a new period of global growth that is more equitable and contributes to unprecedented wellbeing.

\section{Industrialisation and environment}

The natural system possesses self-regulating mechanisms, which are composed of a complex web of positive and negative feedback systems operating within the context of the carrying, regeneration and assimilation capacity of the respective ecosystems. However, the industrialisation of the past two centuries changed the ecological dynamics in ways that no one could have imagined. The utilisation of coal led to steam engines, and machines replaced land as the central means of production. This development led to great material productivity and a world that today supports, at least partially, more than seven billion people. The expansion of industrialisation led to environmental deterioration from the poles to the tropics, from the top of the mountains to the ocean depths (Meadows, Meadows \& Randers, 1992). The success of the industrial transformation, like the more limited successes of the agricultural transformations, led to ecological scarcities, not only in terms of natural resource supply but also in terms of the absorptive capacity of the natural sinks and species losses.

Thomas Robert Malthus (1766-1834) is considered to be the first economist to foresee the limits to growth caused by resource scarcity. While he fits into the classic economics tradition, Malthus is sufficiently at variance with some basic principles (Oser \& Blanchfield, 1975). By 1798, many of the evil effects of the industrial revolution had surfaced. Unemployment, poverty, and disease were already problems calling for remedial treatment. Contrary to the ideas of William Goldwin (1756-1836) and Marquis de Condorcet (1743-1794), Malthus said that the vices and misery that plague society are not due to evil human institutions but are due to the fecundity of the human race (Oser \& Blanchfield, 1975). This led to his theory of population dynamics. According to Malthus's theory, population, when unchecked, increases geometrically while subsistence increases arithmetically, at best (Oser \& Blanchfield, 1975).

Together with David Ricardo (1772-1823), who fundamentally agreed with his population theory, Malthus expressed his 'environmental limits thinking' in terms of the limits on the supply of good quality agricultural land and the resultant diminishing returns in agricultural production (Pearce \& Turner, 1990). For Malthus, the fixed amount of land available meant that as the population grew, 
diminishing returns would reduce the per capita food supply. The standard of living would be forced down to a subsistence level, and the population would cease to grow. Diminishing returns set in, not so much because of absolute scarcity, but because the available land varied in quality. The fundamental shortcoming of this theory is that, in both cases, the subject of diminishing returns was defined based on keeping the total production curve fixed (Pearce \& Turner, 1990). In reality, technical innovations, such as the use of fertilisers, have shifted the total production curve upwards, increasing output per unit of input and offsetting the tendency towards diminishing returns. Despite such limitations, the Malthusian theory of 'environmental limits' may be considered a precursor to some of the fundamental principles of sustainable development (Mebratu, 2000).

On the political economy front, Roszak (1989) concluded that it would be no exaggeration to call Ernst Schumacher the Keynes of post-industrial society, by which he meant a society that has left behind its lethal obsession with those mega systems of production and distribution that Keynes tried so hard to make manageable. The first work of Schumacher appeared in 1959 under the title, The Crucial Problems of Modern Living. His works culminated in international recognition and fame after the publication of his famous book, Small is Beautiful, in 1979. The themes addressed in this book included:

sharp criticism of over-organised systems as destructive of the human spirit and the planet alike;

concern about the rapid depletion of natural resources and the corresponding destruction of the environment;

the concept of intermediate or appropriate technology and the importance of human scale, perhaps the concept for which the book is best known;

$\square \quad$ the failure of traditional economics to bring incommensurable 'noneconomic factors' into the policy-making process; and

a need for human beings to be close to the nurturing land, in both fact and spirit (McClaughry, 1989).

To a world awakening to the spectre of global pollution, resource exhaustion, corporate concentration, and the corresponding diminution of individual liberties, Schumacher's book was 'a ray of hope' (McClaughry, 1989). As a result, in the mid-1970s, 'Small is Beautiful' became a rallying cry while the concept of appropriate and intermediate technology became the catchphrase of the following decade. Although the book contains some controversial and debatable ideas, Schumacher's concern about the exhaustion of the planet's resources gave new impetus to a whole generation of environmental defenders. His effort of looking 
at the economic, ecological, and social aspects of a given system added a new dimension to the discourse on the 'scale of organisation.'

Since the middle of the twentieth century, there have been numerous efforts to address the environmental impacts of industries. Initially, most of the efforts were limited to the reduction and/or containment of the adverse effects of industrial activities on human health through the end-of-pipe management of industrial wastes. As a result, since the middle of the twentieth century, many end-of-pipe management technologies and techniques that included treatment and disposal techniques were developed and introduced. While such measures led to the improvement of the ambient environmental conditions in some areas, it was not sufficient to fully contain or reduce the pollution impact. The publication of Rachel Carson's Silent Spring, a book on the global problems of pesticides published in 1962, heralded the arrival of the contemporary environmental era that was characterised by a flurry of environmental activities in the developed world in the subsequent decade (Mebratu, 2000). As a consequence, the focus shifted to the broader objective of reconciling industrial activities with the ecological balance of the natural system starting from the mid-1970s. This required a fundamental rethinking of industrial structures and operations which led to the evolution of different concepts related to sustainable industrial development, as highlighted in the next subsection.

\section{Sustainable industrial development tools}

As was noted in earlier sections, the industrial development path that had been followed by many of the industrialised countries until the middle of the twentieth century had been exclusively based on uncontrolled and unlimited extraction of natural resources and discharge of industrial pollutants. This led to numerous environmental havocs, which in turn led to public dissent and outcry in most of the developed countries in the nineteen sixties and seventies. As a result, the improvement of the environmental performance of industries at the plant level through the application of end-of-pipe management techniques and technologies became the primary focus of industries. The process that started as an end-of-pipe management exercise has subsequently led to looking back at the whole process of production in the nineteen-eighties and nineties. This led to the evolution of numerous concepts that are aimed at improving operational performance at various levels.

Three major aspects of industrial operations have emerged as the principal foci of the environmental performance improvement at the plant level. These are organisational management, product development, and production processes. The introduction of environmental management systems (EMS), extended producer 
responsibilities (EPR), and eco-industrial parks (EIPs) development are the three major industrial development tools that constitute the organisational interventions for sustainable industrial development. An EMS is a system by which a company controls the activities, products and processes that cause, or could cause, environmental impacts and in doing so minimises the environmental impacts of its operation (Roberts \& Robinson, 1998). Extended producer responsibility assists in reaching an environmental objective of a decreased total environmental impact from a product by making the manufacturer of the product responsible for the entire lifecycle of the product. This especially includes the take-back, recycling and final disposal of the product (Lindhqvist, 1998). Taking the concept of an ecosystem as a basis, an eco-industrial development is defined as a community of local administration, manufacturing and service businesses seeking enhanced socio-economic and socio-ecological performance through collaboration in managing environmental and resource issues including energy, water, and materials (Mebratu, 2000:87).

Table 4.1 summarises key features and impacts/outcomes of the major tools for sustainable organisational management.

Table 4.1 Tools for sustainable organisational management

\begin{tabular}{|l|l|l|l|}
\hline Category & Major tools & Key features & Impacts/Outcome \\
\hline & $\begin{array}{l}\text { Environmental } \\
\text { management systems }\end{array}$ & $\begin{array}{l}\text { Promotion of continuous } \\
\text { improvement }\end{array}$ & $\begin{array}{l}\text { Reduction of pollution discharges } \\
\text { and impacts }\end{array}$ \\
\hline $\begin{array}{l}\text { Organisational } \\
\text { management }\end{array}$ & $\begin{array}{l}\text { Extended producer } \\
\text { responsibility }\end{array}$ & $\begin{array}{l}\text { Promotion of reuse of materials } \\
\text { through a take-back system }\end{array}$ & $\begin{array}{l}\text { Higher resource reuse and better } \\
\text { management of toxic substances }\end{array}$ \\
\cline { 2 - 4 } & Eco-industrial parks & $\begin{array}{l}\text { Promotion of industrial symbiosis } \\
\text { between industries }\end{array}$ & $\begin{array}{l}\text { System-level efficiency on } \\
\text { resource use and recycling }\end{array}$ \\
\hline
\end{tabular}

Sustainable product development and development of product-service systems constitute the two major technical shifts observed in the area of product design and development. Sustainable product development is defined as resource-, context-, and future-oriented product development, aimed at the fulfilment of primary needs, a better quality of life, equity, and environmental harmony over the whole life cycle of a product (Van Weenen, 1997:15). The product-service system focuses on continuous improvement of the functional service provided by products while reducing the overall resource and environmental impacts of the product over its lifetime (Mebratu, 2000). Under such systems, the consumers only pay for the services they acquire from a given product while keeping the ownership of the products with the producers or leasing agents, thereby reducing the systemic deposition of post-consumer products in the natural system. The progress made in this area has led to a significant reduction of the material and energy intensity of successive generation of products. 
Table 4.2 summarises key features and impacts/outcomes of the major tools for sustainable product development.

Table 4.2 Sustainable product development tools

\begin{tabular}{|l|l|l|l|}
\hline Category & Major tools & Key features & Impacts/Outcome \\
\hline $\begin{array}{l}\text { Product } \\
\text { development }\end{array}$ & $\begin{array}{l}\text { Sustainable product } \\
\text { development }\end{array}$ & $\begin{array}{l}\text { Optimising the life-cycle impact } \\
\text { of a product }\end{array}$ & $\begin{array}{l}\text { Reduction of the material and } \\
\text { energy intensity of a product }\end{array}$ \\
\cline { 2 - 3 } & $\begin{array}{l}\text { Product-service } \\
\text { systems }\end{array}$ & $\begin{array}{l}\text { Optimising product functionality } \\
\text { and service delivery of products }\end{array}$ & $\begin{array}{l}\text { Reduction of resource extraction } \\
\text { and habitat destruction }\end{array}$ \\
\hline
\end{tabular}

The introduction of cleaner production (CP), resource efficiency and green industry represent significant milestones of the transition within industrial production systems. The first United Nations Environmental Programme (UNEP) International High-level Seminar held in 1990 defined cleaner production as the continuous application of an integrated preventive environmental strategy applied to processes, products and services to increase eco-efficiency and reduce risks for humans and the environment (UNEP, 2002:08). Resource efficiency is a systematic and integrated approach to managing raw material, energy, water and chemical inputs efficiently while eliminating or minimising wastes and emissions from an industrial system on a sustainable and cost-effective basis (UNEP \& United Nations Industrial Development Organization [UNIDO], 2010:11-12). Green Industry means economies striving for a more sustainable pathway of growth, by undertaking green public investments and implementing public policy initiatives that encourage environmentally responsible private investments (UNIDO, 2009).

Table 4.3 summarises key features and impacts/outcomes of the major tools for sustainable production.

Table 4.3 Tools for sustainable production

\begin{tabular}{|l|l|l|l|}
\hline Category & Major tools & Key features & Impacts/Outcome \\
\hline $\begin{array}{l}\text { Production } \\
\text { processes }\end{array}$ & Resource efficiency & $\begin{array}{l}\text { Reduction of waste } \\
\text { generation at the source }\end{array}$ & $\begin{array}{l}\text { Improved resource utilisation and } \\
\text { reduced pollution discharge }\end{array}$ \\
\hline & Green industry & $\begin{array}{l}\text { Inom a life-cycle approach } \\
\text { fromoting sector-wide }\end{array}$ & $\begin{array}{l}\text { Reduction of resource and pollution } \\
\text { intensity per unit output }\end{array}$ \\
\hline $\begin{array}{l}\text { transformation through } \\
\text { strategic intervention }\end{array}$ & $\begin{array}{l}\text { Development of new products and } \\
\text { sectors that are resource efficient } \\
\text { and inclusive }\end{array}$ \\
\hline
\end{tabular}

Even if the above-highlighted tools were presented as a cluster for ease of understanding and presentation, most of them are very interdependent on one another right from their development stage through implementation. The major influences of these and other evolving concepts can be categorised under the following points (Mebratu, 2000): 
Market restructuring: Some of the evolving concepts and tools enhance the market restructuring process by facilitating the creation of a new segment of consumer behaviour that has a preference for environmentally friendly products. In this context, the number of consumers that demand a certain level of environmental quality from products and services is on the rise. The recognition given to different kinds of environmental (eco-) labelling schemes as a marketing tool is an outcome of this change, and this is expected to influence the global market structure and global value chain.

Technological innovation: Environmental considerations promoted through the various concepts and tools act as one of the significant drivers of technological innovations in product design and processes development. This has led to the evolution of new generations of technologies that are both ecologically and economically efficient. The advance that is being made in product and process development is expected to influence the nature of technology transfer from the industrialised world to the developing world and vice versa.

Organisational innovation: Most of the concepts that are evolving in response to environmental challenges have triggered a corresponding organisational innovation process. The critical element of this organisational innovation process is the development of a learning organisation that is responsive to the dynamic changes. This has posed a challenge to all levels of an organisation including the demand for organisational change in the major global institutions.

In general, the evolving tools and concepts and their subsequent influence on the industrialisation process are clear indicators of the beginning of a new transformation process. This process is going to pose a significant challenge to African economies in terms of keeping and increasing their industrial product's share in the global market. However, it also creates a vast opportunity of leapfrogging to more inclusive, resource-efficient and low-carbon economies. In this context, Africa needs to keep pace with these evolving concepts and tools and make its contribution to the transformation process, if it desires not to be left behind.

\section{Industrialisation and Africa}

The onset of industrialisation in Europe unleashed a growing appetite for natural resource inputs that went beyond the regenerative capacity of the natural systems in European countries. This led to a more concerted effort of colonising countries in the form of complete occupation or colonising and using them as a source of raw materials input. African countries have been aspiring to industrialise their 
economies since their early years of liberation. These aspirations were reflected in the development and promotion of some main regional and national industrial development strategies. Unfortunately, the overall progress made in bringing about the desired structural transformation in African economies was minimal. This section highlights the major features of the main strategies and the performance of the industrial sector over the last couple of decades with the purpose of identifying the key lessons that need to be considered.

\section{Industrialisation strategies and initiatives}

A broad overview of industrial development strategies in Africa shows that there have been three major groups of development strategies that attempted to influence national development strategies in Africa. The first group consists of strategies associated with the adoption of the Lagos Plan of Action (LPA) as a postliberation strategy of industrialisation. This was subsequently encapsulated within the New Partnership for Africa's Development (NEPAD) that was developed as Africa's development blueprint in the twenty-first century. The second group of industrialisation strategies are associated with national strategies that were promoted through the Industrial Development Decade for Africa (IDDA). The third group of industrialisation strategies are associated with the broad economic policy influence that was imposed by the global financing institutions such as the World Bank and the International Monetary Fund. This includes the structural adjustment programmes (SAPs) that were imposed in the 1980s and 1990s.

The LPA is perhaps the most important regional economic development strategy that was developed after a thorough assessment of the state of African socioeconomic development, towards the end of the 1970s. The Lagos Plan of Action and the Final Act of Lagos for the collective industrialisation of Africa was adopted by member states of the Organization of African Unity (OAU) as a regional economic development blueprint. The adoption of the LPA was based on the two principles of self-sustained and self-reliant industrialisation. The Lagos Plan of Action, designed jointly by all countries of Africa, constitutes a charter for the development of the continent for the period 1980-2000. The Final Act of Lagos, adopted in 1980, generated a feeling of optimism and expectation that the last two decades of the century would witness a significant breakthrough in African economic and social development and establish a firm foundation for progress in the twenty-first century.

The LPA not only emphasised industrial growth but, more specifically, selfsustained industrialisation designed to meet domestic needs. According to UNECA, many strategic measures were proposed, including the following: 
Building up of an industrial production structure capable of meeting changing domestic needs through the preparation and implementation of an integrated industrial development programme.

Establishment of a core of production, marketing, research and development activities which provide the impetus for economy-wide growth processes.

Selection of products appropriate to the satisfaction of the basic needs of the mass of the population and the promotion of self-sustaining development.

Expansion and restructuring of domestic markets by integrating the rural economy with the modern sector through the construction of the necessary infrastructure.

$\square$ Sub-regional economic integration aimed at developing basic and capital goods industries in integrated sub-regional markets.

Generation and use of information and data in economic planning and decision making. (UNECA, 1980)

The concept of structural adjustment programmes, as commonly used in the 1980s, has its origins in the global economic events of 1973-1974 and the first oil shock (Reed, 1992). Throughout the later parts of the 1970s, the International Monetary Fund (IMF) and national governments took many crisis management measures, but with few positive results. It is under such circumstances that the World Bank decided to commit its resources to help correct the pervasive macroeconomic imbalances (Mosley, Harrigan \& Tate, 1991). The SAP package is based on the belief that the market is a more efficient mechanism for promoting optimum resource allocation than state planning and 'dirigisme'. It covered the adoption of realistic exchange rates that reflect the true value of a country's currency and the promotion of exports without placing a premium on imports; interest rates that are higher than the inflation rates and that will, consequently, encourage savings; trade liberalisation and the removal of bureaucratic constraints and controls on exports and imports; the avoidance of large budgetary deficits; and the avoidance of artificial subsidies (Rasheed \& Luke, 1995).

According to UNECA (1991), the analysis of the evaluation carried out by the World Bank in 1988 indicated that sub-Saharan African countries implementing structural adjustment programmes experienced a severe economic decline after the adoption of SAPs. According to this report, sub Saharan African countries' economies registered a decline in gross domestic product (GDP) growth from 2.7 percent to 1.8 percent, a decline in the investment/GDP ratio from 20.6 percent to 17.1 percent, a rise in the budget deficit from -6.5 percent to -7.5 percent of GDP and a rise in debt service/export earnings ratio from 17.5 percent to 23.4 percent. 
The only improvement was a minor decline in the current account/GDP ratio from -9.4 percent to -6.5 percent. UNECA (1991) concluded that both on theoretical and empirical grounds, the conventional SAPs were inadequate in addressing the real causes of economic, financial, and social problems facing African countries which are of a structural by nature. The big question that was raised by all parties was why adjustment did not lead in Africa to its intended consequences.

From the perspective of the World Bank and the IMF, the cause of Africa's malaise was a direct result of the policies pursued by the governments of Africa before the introduction of SAP. However, others argue that the reason is more than policy failures on the African government side, even if this has contributed. Howard Stein argues that the reason is mainly theoretical. According to Stein (1998), SAPs adjustment theories have their roots in neo-classical economic theory which is severely flawed as a guide to understanding how to build economies capable of structural transformation and sustainable development. In other words, it is not an implementation problem but a conceptual problem. Stein further noted that the thinking behind the model is rational deductive and axiomatic and the apparent problem with the approach is that the need for adjustment is a product of the model of adjustment, and the model of adjustment is a product of a series of theoretical premises of abstraction. Thus any divergence of the real cause from the premised cause will lead to severe errors in the realm of policy formulation and implementation (Stein, 1998).

The Industrial Development Decade for Africa (IDDA) was developed based on the LPA and the concept of the United Nations Development Decade. The development of the IDDA was based on the recognition of the persistence of at least three significant structural weaknesses, namely dependence on a few primary export commodities, dependence on broadly the same markets for selling primary commodities and for buying capital and consumer goods and services, and persistence of market enclaves and dysfunctional relations within national economies (UNIDO, 1982). The Industrial Development Decade for Africa was based on the much broader concept of designing and constructing internal engines of growth in Africa to replace the prolonged and accelerating weakening of an external engine of growth resting on trade and economic relations with the developed economies of western Europe and the United States. The IDDA programme, which consists of objectives, principles and priorities, constitutes one small but crucial component in the design, construction and working of the internal engine of growth that was enshrined by the LPA. The heart of the programme was the production, supply and use of factor inputs for designated core industries and the use of the outputs of core industries for promoting the growth of strategic sectors. 
During the earlier part of the first IDDA, some public investments were made in industrial projects, although funding and other constraints did not permit investments of the desired scale. Well-intentioned as these investments were, they were not successful. According to a report by the Economic and Social Council (ECOSOC) of the UN (1992), massive problems have arisen in technology absorption, machinery maintenance and management. The net results were that input-output ratios were sub-optimal, consumption coefficients were below standard, productivity was low, and capacity utilisation was below the break-even point. According to this report (UN, 1992), it was roughly assessed that the average capacity utilisation of the African industries ranges between 30 to 40 percent. As a result, many of the industries set up were running at a loss, and some were at a point of bankruptcy. Since many of these plants were in the public sector, they were kept going through state subsidies and thus became a burden to the nations.

IDDA-2 and IDDA-3 have followed the first IDDA in the subsequent decades. The main goals of the second and third IDDA are not fundamentally different from those adopted for the first decade. The vision continued to be that of a programme to end the over-dependency which African countries have on the industrialised world, to promote internal engines of growth, to build on Africa's wealth and natural resources and progressively to achieve self-reliance and self-sustainment. However, it was claimed that there had been a significant departure in the 'modus operandi' of preparing the programme for the second IDDA (Organization of African Unity [OAU], Economic Commission for Africa [ECA] \& UNIDO, 1997) and preparations of the plan for the second IDDA have moved to the national level. Each member state has undertaken the task of framing a national programme for the second IDDA keeping in mind the realities, environmental circumstances, natural resources and priorities of each member state. This is mainly due to the experiences of the first decade, the changing world environment and the adoption, by a large number of African countries, of World Bank sponsored structural adjustment programmes.

In general, the IDDA process was profoundly influenced by the philosophical foundation of the LPA which promotes the interventionist approach with heavy reliance on state planning and control. This approach has led to the continuous undermining of the development of the private sector and the marginalisation of the existing private sector from the development process (Mebratu, 2000). Furthermore, as an industrialisation process that is mainly driven by public investment, IDDA was primarily focused on the establishment of largescale industries. As a result, some industrial projects, that were intrinsically uneconomical, were launched in the earlier years of the implementation of IDDA while others that could have been competitive were not given sufficient capability 
and institutional support (World Bank, 1989). This has contributed to the further weakening of national economies in Africa.

There have been different conclusions made on the limitations of development strategies promoted in Africa from different perspectives. Mebratu made the following conclusions after analysing the major groups of regional initiatives developed since liberation:

The regional strategic initiatives spearheaded through the regional bodies were based on the achievement of self-reliance and self-sustainment through active state intervention. On the contrary, the initiatives promoted by the international financing institutions were based on the promotion of a neo-liberal economy that is entirely governed by the market.

The disoriented and often conflicting emphasis on the self-sustainment philosophy of regional strategies and liberalisation of structural adjustment programmes was not able to provide a sound basis for the development of effective development strategies.

All groups of strategies were inclined towards transplanting development either through foreign investment/technology flow and/or through central planning instead of building upon the transformational dynamics of the local socioeconomic factors.

The strategies have weak considerations for socio-ecological factors. In cases where they considered socio-ecological factors, they have been limited to 'environmental policy add-ons' instead of mainstreaming socio-ecological considerations.

All groups of strategies have suffered from frozen policy and strategy frameworks that gave little room for adaptation of the frameworks to changing environments. Their review process was limited to minor tinkering of the performance variables and finding external explanations for the limited successes.

Despite the massive effort of promoting the two groups of strategies, the socioeconomic situation in most African countries became worse in the 1980s. Even if some sub-Saharan African countries have registered improvements in the 1990s, they had a problem of sustaining their socio-economic gains. (Mebratu, 2000:136)

At the dawn of the new millennium, African heads of state and government pledged to take responsibility, through the New Partnership for Africa's Development (NEPAD), for the future of their continent and to establish a new relationship with bilateral development partners and multilateral organisations based on mutual trust, respect and accountability (African Union [AU], 2001). The New Partnership for Africa's 
Development is a comprehensive and integrated sustainable development initiative for the revival of Africa through a constructive partnership between Africans themselves and between Africa and the developed world. It is the first comprehensive development approach initiated, implemented and owned by African governments with the full support of the international community. It provides a vision of the kind of society and economy that African governments want to build. The broad, longterm objectives of NEPAD are to eradicate poverty, put Africa on a sustainable development path, and halt the marginalisation of Africa. In the NEPAD framework document, African leaders identified the following issues and priority areas as crucial for achieving the broad objectives of NEPAD:

Establishing conditions for sustainable development through maintaining peace and security and also improving economic, corporate and political governance.

Promoting investment and policy reforms in priority areas such as infrastructure, human resource development, agriculture, the environment, and science and technology.

Strengthening the mobilisation of resources through, for example, boosting domestic savings as well as official development assistance and private capital flows, reducing external debt, and diversification of production and exports. (United Nations Conference on Trade and Development [UNCTAD], 2012)

The New Partnership for Africa's Development can be considered as a blueprint for African development and industrialisation (Muriithi, 2005). Furthermore, it is not only a development framework, philosophy or vision, but also a development programme with concrete projects geared towards addressing Africa's development needs and challenges. NEPAD is considered as the twenty-first-century version of the Lagos Plan of Action with a new model of partnership between African countries and Africa and its development partners. NEPAD led to the development of many regional framework programmes that are dealing with the key sectors that are crucial for Africa's development. One of these programmes is the Programme for Infrastructure Development in Africa (PIDA). This programme mainly focuses on the development of energy infrastructure as a driver for industrial development in Africa. Even if they were launched with much optimism, the implementation of NEPAD programmes, including PIDA, has not been as successful as it was expected.

\section{Trends of industrial development in Africa}

As noted in the earlier section, until the end of the nineteen seventies the national development strategies of most African countries promoted active state intervention in development planning and implementation. Throughout the subsequent decades, development strategies of most African countries moved between the two 
extreme positions of active state intervention and laissez-faire approaches, with very few countries exclusively endorsing one or another form of the strategy. The development effort spearheaded by the development decade concept led to some positive, but not satisfactory results in the areas of social development. For instance, between 1960 and 1994, life expectancy increased from 40 years to 52 years, while since the mid-1980s the proportion of the population with access to safe water was almost doubled, from 25 percent to 43 percent of the total (Spark, 1998). During the same period, adult literacy advanced from 27 percent to 55 percent. However, the economies of most African countries declined in virtually every measurable way from the 1970s through to the mid-1990s.

Most of these economies declined in terms of GDP and per capita GDP after an impressive start at independence. Rodrik (2016) points out that the low-income economies of sub-Saharan Africa have been affected nearly as much by what he called 'premature deindustrialisation' as the middle-income economies of Latin America - though there was less manufacturing, to begin with in the former group of countries. The trade liberalisation policy that was pushed through globalisation is believed to have made a significant contribution to the transition of most sub-Saharan African economies to service economies before having meaningful industrialisation. This laid the basis for what is called 'premature deindustrialisation. On the other hand, Africa's debt has grown geometrically during the period from the 1960s to the 1990s. In 1960, the region's external debt amounted to less than three billion USD, and the average debt service ratio was only 2 percent of exports. In 1996, the region's aggregate ratio of debt to exports was estimated at 239.9 percent (UNECA, 1996). Africa has also been missing from the massive expansion of international trade. Africa's share of global trade has fallen from around 3 percent in the 1950s to about 1 percent in 1995.

Since the turn of the century, however, some African countries started showing signs of economic recovery as reflected in the sustained growth rate in their national GDP. According to UNECA, around twenty African countries registered an average GDP growth of more than 5 percent during the period from 2000 to 2014 and more than half of African countries registered an average GDP growth rate of more than 4 percent during the same period. Only four countries that are plagued with internal conflict and war registered negative GDP growth during the same period (UNECA, 2016a). McKinsey Global Institute (2016) reported that Africa's real GDP grew at an average of 3.3 percent a year between 2010 and 2015, which is considerably slower than the 5.4 percent from 2000 to 2010. It, however, also noted that this average disguises stark divergence as growth slowed sharply among oil exporters and North African countries while the rest of Africa posted accelerating growth at an average annual rate of 4.4 percent in 2010 to 2015, compared with 4.1 percent in 2000 to 2010 . 
The improved economic growth rate registered over the last two decades led to the change of the narrative about Africa's prospect for economic development as captured by an article in The Economist, 'The Sun shines bright' in 2011 and Time magazine's piece, 'Africa Rising', in 2012 (UINECA, 2016b). The proponents of this narrative (Andersen \& Jensen, 2013; McKinsey Global Institute, 2010; Radelet \& Sirleaf, 2010; Robertson, Mhango \& Moran, 2012) gave some reasons to explain why this time around the growth has come to stay. This includes an increase in the number of democracies and a more open political domain; a significant drop in the level of violence from 55 percent to 24 percent (Africa Progress Panel [APP], 2012); and lessons have also been learned from the policy mistakes of the 1960s and the 1970s. In addition, some claim that a technological revolution has taken hold across the continent, most dramatically illustrated by an increase in the use of cellular phones.

However, there are numerous criticisms and reservations expressed with the support of some rigorous and more nuanced analysis of economic growth trends of African countries which showed that the 'Africa rising' narrative misses out many essential points. Rodrik (2017) argues that without manufacturing gains, the growth rates brought about recently by rapid structural change in low-income African countries are exceptional and may not last. UNECA (2016b), highlighted the following as some of the major reservation points expressed by different groups:

Over the same period under consideration, per capita growth in developing countries in East Asia and Pacific countries (EAP) averaged 7.71 percent, whereas developing countries in Africa registered 2.09 percent. This means that developing countries in EAP have been growing over three times faster than those in Africa.

As was pointed out by Arbache and Page (2009), the improved economic performance in Africa after 1995 can be mainly attributed to the increase in growth accelerations of resource-dependent countries that created a commodity price boom. This makes the sustenance of this relatively modest growth performance unlikely in the long run for most countries.

Even if Africa can sustain its recent growth performance, the poor quality of recent growth in Africa in terms of employment and poverty makes it doubtful that it will have significant positive impacts on the lives of most people.

The ILO (2014) reported that in 2013 the vulnerable employment rate in Africa (excluding North Africa) was estimated at 77.4 percent of all jobs, the highest of all developing regions in the world. This is only 2.3 percentage points lower than in 2001. 
From 2000 to 2011, the population share in Africa (excluding North Africa) living on less than $\$ 2$ a day $(\mathrm{PPP})^{1}$ was reduced from 77.5 percent to 69.5 percent showing that Africa's recent growth was also of poor quality in terms of its impacts on poverty.

From 1980-2013, the share of manufacturing in economic output on the continent declined from more than 12 percent to around 11 percent, currently the lowest of all developing regions in the world. (UNECA, 2015)

UNECA (2016b) concludes that Africa is doing better in many ways compared to 15 years ago. However, in terms of the development of productive capabilities, which is the essence of sustained economic development, one can conclude that the 'Africa rising' narrative is mostly hype. On top of all these, most of the rise in GDP is associated with sales of commodities from extractive sectors, which left behind a huge environmental cost to the countries. Paul Cilliers (2010) notes that resourcedependent growth tends to stimulate short-term growth but could undermine long-term growth. Further growth and development will, therefore, depend on whether revenues from resource rent are re-invested in laying the foundation for long-term development. Furthermore, the growth in national GDP that has been applauded by the 'Africa rising' proponents will essentially be wiped out when we account for the cost of environmental degradation and destruction caused by these extractive industries. Africa as a whole is still projected by the IMF to be the world's second-fastest-growing economy to 2020. Nonetheless, most African countries are yet to go through the essential process of structural transformation and reverse the recent trend of deindustrialisation.

\section{Inclusive and sustainable industrialisation}

The fast rate of socio-economic development witnessed over the last couple of centuries has clearly shown that the development of the industrial sector in general and the manufacturing sector, in particular, is the primary engine for economic growth. Recent economic history has also shown that industrial development that is exclusively driven by profit maximisation and wealth accumulation leads to significant damage to the natural ecosystem and exclusion of billions of people from economic prosperity. Progress made in the development of more resourceefficient production technologies and techniques has also shown that newly developing countries do not need to follow the same old inefficient and polluting paths of industrialisation that have been followed by industrialised and newly

1 Purchasing power parity (PPP) is a macroeconomic analysis metric to compare economic productivity and standards of living between countries. It is an economic theory that compares different countries' currencies through a 'basket of goods' approach. 
emerging countries. As a result, there is a growing global consensus that underlines that economic development in the twenty-first century has to be inclusive, low carbon and resource efficient.

In this subsection, we will look at some of the major sustainable industrial development tools that are relevant to Africa's industrialisation and propose a framework for sustainable industrial development, which could be adopted and implemented by African countries.

\section{Strategic considerations for inclusive and sustainable industrial development}

Looking back at the economic history of Africa over the last two centuries, it is evident that the region has mostly missed all three stages of the industrial revolution. We are now faced with the prospect of the fourth industrial revolution, which is expected to have a much higher impact on their economies. Depending on how they prepare and position themselves, African countries would either be further marginalised from the global economy or be an active contributor and beneficiary from this transition. African countries need to focus on developing an inclusive and sustainable industrial development policy framework in order to be active players and beneficiaries of the industrial revolution of the twenty-first century. Such a framework has to enhance national capacity to overcome the challenges of getting locked-in in an obsolete and inefficient industrial infrastructure and provide the basis for effective utilisation of emerging efficient systems and technologies for the improvement of the wellbeing of its people.

Industrial policy is about anticipating important long-term trends of technology and market development and providing incentives to adopt the structure of a national economy in such a way that it can take advantage of the change (Partnership for Action on Green Economy [PAGE], 2017). Besides understanding the current and emerging economic and technological dynamics, there are some key lessons that African countries should consider from the success and failure of the major regional and national industrial development policies and strategies that have been implemented in the last couple of decades. The following are some of the critical issues that need to be considered in developing and implementing an inclusive and sustainable industrial development policy:

Targeted public sector investment on development of the physical structure required for industrial development has a significant catalytic role to play, particularly if it focuses on developing the highly needed energy, transportation and communication infrastructure. However, such investment needs to be coupled with building the required capacity for the effective management 
and operation of such infrastructural facilities. Building such infrastructure with external debt and giving the management of their operation to foreign companies, as it is happening in some African countries, is not a right strategy that leads to an inclusive and sustainable industrial development.

The most critical infrastructural prerequisite for industrialisation is the institutional infrastructure, which includes creating the required human skill-sets and institutional systems that drive the industrialisation process. Development of an effective industry-university linkage is one of such institutional system besides having a sound and context-relevant policy environment. Most of the investment that went into the development of huge physical infrastructure across the region so far largely failed to deliver due to the limitations in institutional infrastructure development.

Enhancing national capacity on effectively managing the selection and transfer of industrial manufacturing technologies is a crucial prerequisite for successful industrialisation of any country. African countries need to recognise that they can never industrialise by becoming a dumping ground for obsolete and inefficient industrial production processes in the name of foreign direct investment (FDI). This is particularly a critical issue now when we consider the progress that is being made in different sectors towards more resource-efficient industrial systems, which has created the condition for shifting and relocating polluting industries to African countries under the guise of FDI.

Promoting the development of a dynamic and adaptive innovation ecosystem that is responsive to emerging technological trends based on creativity of its youth is a critical success factor for any African country. The innovation space of the twenty-first century is becoming fundamentally different from the conventional innovation systems supported by public institutions. The growing influence of open spaces and creative commons as public innovation platforms is opening new opportunities and relationships among innovators and entrepreneurs. Coupling such innovation ecosystems with different forms of blended financing is a key determinant of leapfrogging to a highefficiency trajectory.

African countries should recognise that industrialisation does not involve an either-or choice between import substitution and export promotion. Rather than focusing on such false dichotomy, countries should focus on an industrial strategy that deploys a combination of these components with a focus on maximising the return from their comparative advantages and improve the wellbeing of its people through job creation and higher value addition to the local resource. 
African countries need to prepare themselves to contain the adverse impact and maximise the benefit from the opportunities of digitisation of the global economy. They should make a maximum effort to exploit the emerging opportunities created by recent development in disruptive technologies. This includes the opportunities from development in the application of artificial intelligence including block-chain technologies, distributed energy systems driven by renewable energy resources, and distributed manufacturing systems that include modularisation of industrial processing technologies. This is crucial not only for their exponential economic impacts but also because of their significant distributional outcomes that promote or discourage inclusivity.

Industrial development policies of African countries should particularly need to consider the possible impacts and positive contributions of disruptive technologies, such as block-chain technology, on the global value chain. The potential benefit it could provide in terms of facilitating sustainable supply chain and distributed manufacturing systems are two key benefits on which African countries should mainly focus. This is because of their significant contribution to local value addition and job creation.

Development of industrial parks or estates, which has been promoted as a key element of industrial development strategy since the middle of the twentieth century, has made a significant contribution to the industrialisation of developing countries. However, the economic gains often come at a considerable loss of environmental quality and social impacts within and around industrial estates. Experience from many developing countries has shown that ecological and social issues have often not been adequately considered and integrated into the planning and development of industrial parks. As a result, their industrialisation has come at a considerable cost of environmental pollution and degradation and social displacement. African countries can overcome such challenges by developing eco-industrial parks that are effectively integrated, horizontally and vertically, with local economies and are resource efficient.

History and experience demonstrate that urbanisation is closely linked to economic growth and the transformation of economies towards productive sectors, namely industry and services. Available evidence suggests that urban and industrial development in Africa is disconnected, resulting in lost opportunities for job creation and improved wellbeing. Reconnecting urban and industrial development in Africa through deliberate policies, strategies and investments is a priority for the sustainability of both cities and industries (UNECA, 2017). 


\section{Box 4.1: Lessons for the development of eco-industrial parks}

Industrial parks (IPs) in emerging and developing countries provide an institutional framework, modern services and a physical and often social infrastructure, which might not be available in the rest of the country. The concentration of companies can foster innovation, technological learning and company growth. Economies of scale of the supply of services and facilities reduce the costs for companies; thus successful IPs contribute to high-growth regions and national economic development. However, the economic gains often come at a loss of environmental quality within and around industrial estates. This is because environmental issues have often not been adequately considered and integrated into the planning and construction of IPs (UNEP, 2001).

An industrial park in which companies cooperate with one other and with the local community trying to reduce waste and pollution, efficiently share resources and help to achieve sustainable development, with the intention to augment economic gains and improve environmental quality, can be called an eco-industrial park (EIP). The reported potential advantages of environmental management at the level of industrial parks include the following:

- IPs are in line with international standards, and therefore the environmental management practices of IP companies become gradually in line with these standards.

- Environmental management should rely on measurements to achieve high efficiency.

- Environment affects investment, and EIPs put more effort into controlling environmental quality than regular areas.

- EIPs can serve as special designated areas to test new environmental management practices and advanced instruments.

An industrial zone, sector or park can turn into an eco-industrial park through the combination of:

- plant-level efficiency: resulting in minimisation of waste and emission generation from individual enterprises;

- collective synergies: resulting in optimised resource exchanges between companies;

- common environmental and utility systems and management of park operations; and

- proper zoning and planning.

One of the main recommendation informed by the various case studies is that EIPs are valuable especially in developing and emerging countries as they are beneficial in the form of local infrastructure and environmental, economic and social benefits. Therefore, governments and international organisations should promote the development of EIPs.

(Source: Adapted from UNIDO, 2016:4)

\section{Framework for inclusive and sustainable industrial development}

Taking the above points and other issues highlighted in this chapter into consideration, the framework for inclusive and sustainable industrial development, highlighted in Figure 4.1, is suggested. The framework is proposed as a generic framework that could be further adapted in response to the specific contexts and 
needs of each country. To this effect, it focuses on vital elements of infrastructure that are necessary for the development of an inclusive and sustainable industrial economy. These are clustered under four group of infrastructure, namely institutional, physical, technological, and compliance assistance infrastructure.

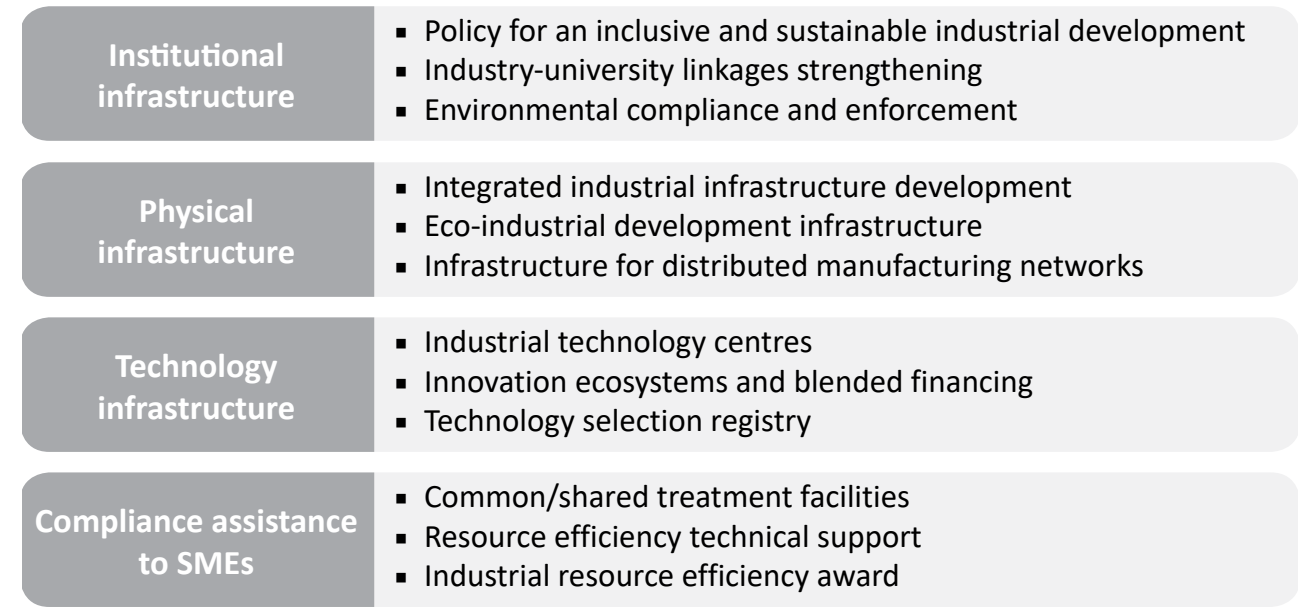

Figure 4.1 Framework for inclusive and sustainable industrial development

The four subsections that follow explore each of these interventions in turn. Note, however, that even though the elements of intervention have been clustered in four groups, it is essential to note that their development and implementation has to be carried out in an integrated manner. This is important to have a more synergistic effect while at the same time assist in avoiding operation bottlenecks that are caused by missing one of the elements.

\section{Institutional infrastructure}

The key element of the institutional infrastructure is the development of a policy for an inclusive and sustainable industrial development that takes into account the lessons and issues highlighted under this section. To ensure the soundness and context-relevance of the policy framework and ensure its effective implementation, African countries need to make the maximum possible effort to strengthen industry-university linkages. While most African countries do have environmental regulations that are sufficiently detailed, they significantly lack the appropriate institutional process and structure for their enforcement. Hence, in parallel with the development of the sectoral development policy framework, they need to put in place a function of environmental compliance and enforcement mechanisms. This may include the establishment of an Environmental Court that is dedicated explicitly for adjudicating environmental complaints to be made by the public. 


\section{Physical infrastructure}

Development of the necessary physical infrastructure that is required for efficient industrial operation is a fundamental prerequisite for any meaningful industrial development process. This includes energy, water, communication, transportation and environmental management infrastructure that are necessary for industrial operation. The most critical issue in this regard is to develop these infrastructures in an integrated manner with primary attention on avoiding any operational bottlenecks that could be caused by lack of delay of one of these infrastructures. One effective way of achieving such an integrated infrastructural service provision is the development of eco-industrial parks that are effectively integrated with the local and national economies. While the development of EIPs as the backbone of the industrial development strategy is essential, it will be necessary for African countries to give equal attention to the development of distributed manufacturing infrastructure as an essential vehicle for job creation and value creation at the local level. Properly designed and developed EIPs could serve as a strategic anchor for developing such distributed manufacturing networks.

\section{Technology infrastructure}

Development of dedicated technology infrastructure is of vital importance in light of the significant developments in the field of industrial resource efficiency and the critical role that existing and emerging disruptive technologies would play in industrial operation in the twenty-first centuries. Establishment of a dynamic innovation ecosystem with blended financing mechanisms would assist African countries to benefit from the state-of-the-art technologies and techniques that are emerging in connection with specific sectors. Recent developments in the application of ICT have opened enormous opportunities for industrial applications. Supporting the establishment of ICT-based innovation hubs could help African countries to gain the maximum benefit from these applications and also contain the adverse impacts from disruptive technologies. Establishing a technology registry that would be accessible to the industrial community would also enable industrial decision-makers and investors to make an informed decision about available technologies and their related benefits and impacts.

\section{Compliance assistance to SMEs}

Finally, but equally importantly, African countries need to establish a compliance assistance infrastructure that will particularly assist small- and medium-sized enterprises (SMEs). This is critical to meet the national regulatory requirement and to make them competitive in the international market. Given the capacity limitations of most of the SMEs, the compliance assistance infrastructure needs to address both the physical and technical constraints they face. Establishment 
of shared environmental management services and facilities would reduce the significant financial burden for these SMEs, while providing technical support programmes on how to integrate resource efficiency in their industrial operation would enhance their profitability and enable them to comply with the environmental regulation requirement. Complementing these with a recognition scheme on industrial resource efficiency (refer to Box 4.2) would encourage and motivate these industries to become more efficient and competitive.

\section{Box 4.2: AKOBEN: Environmental performance rating of Ghana}

Some African countries have introduced annual award schemes that recognise industrial efficiency improvement at various levels. The most common award scheme that is implemented in some African countries is the awards given for energy efficiency. The environmental performance rating that has been implemented by the Environmental Protection Agency of Ghana (EPA-Ghana) is one of the unique rating systems that is performed by an environmental agency in the region. The AKOBEN programme is an environmental performance rating and disclosure initiative of EPA-Ghana. Under the AKOBEN initiative, the environmental performance of mining and manufacturing operations is assessed using a five-colour rating scheme. The five colours are GOLD, GREEN, BLUE, ORANGE and RED, indicating environmental performance ranging from excellent to poor. These ratings are annually disclosed to the public and the general media, and it aims to strengthen public awareness and participation.

AKOBEN ratings are evaluated by analysing more than a hundred performance indicators that include quantitative data as well as qualitative and visual information. These ratings measure the environmental performance of companies based on their day-to-day operations once they have successfully cleared their environmental impact assessments (EIA) and obtained their environmental permit to operate. These ratings indicate how well companies have met the commitments they made in their EIAs at the planning stage. AKOBEN, therefore, complements the EIA process and serves as a monitoring and verification programme to ensure that companies follow environmental regulations on a continuous basis. Besides creating more motivation both through peer-to-peer and public pressure by publicly disclosing the individual performance of the industries, EPA-Ghana facilitates the provision of technical support to those industries that need to improve their performance through the Ghanaian National Cleaner Production Centre (NCPC-Ghana).

(Source: EPA-Ghana, 2019)

\section{Conclusions}

Industrialising their national economy has been one of the primary preoccupations of successive African governments since the early years of liberation, and it remains to be a priority. However, despite the numerous regional and national efforts made over many decades, none of the sub-Saharan African countries was able to industrialise their economy. On the contrary, most of the African countries have been exposed to premature deindustrialisation as a result of trade liberalisation 
through globalisation. Development of the manufacturing sector is at the core of industrialisation as it tends to be technologically dynamic, absorbs significant quantities of unskilled labour, and it does not face the demand constraints of a home market populated by low-income consumers as it is a tradeable sector (Rodrik, 2016). Hence, it is of paramount importance for African countries to develop their manufacturing sector. However, the development of the manufacturing sector cannot and should not follow the development path of the nineteenth and twentieth century. It cannot because no country could be sustainably competitive in the global market by following the conventional manufacturing development path. It should not because the emerging technological and knowledge trends provide it with unique opportunities to avoid the various pitfalls and drawbacks of industrialisation of the last two centuries.

This chapter highlighted the key lessons that could be drawn from experience and presented the essential tools and opportunities which African countries can utilise in promoting an inclusive and sustainable industrial development. It emphasises that developing an integrated industrial infrastructure that effectively covers the physical, institutional and human components is at the core of the success for any country. This includes the development of eco-industrial parks that are effectively integrated with the local economy, both horizontally and vertically, as the backbone of the industrialisation. Such an approach will provide a strong basis for the promotion and development of distributed economy networks that will serve as a vehicle for job creation and value addition at the local level. All these would require clarity of vision and high-level political commitment that is adequately captured and implemented through national policy and strategy frameworks. I hope the key issues highlighted and covered in this chapter will assist national governments to make an informed decision in their policy direction. 


\section{References}

Africa Progress Panel. (2012). Africa progress report 2012: Jobs, justice and equity. Geneva: APP.

African Union. (2001). New economic partnership for Africa's development. Addis Ababa: African Union.

Andersen, T.B. \& Jensen, P.S. (2013). Is Africa's recent growth sustainable? Discussion Papers on Business and Economics, No. 8, Department of Business and Economics, University of Southern Denmark.

Arbache, J.S. \& Page, J. (2009). How fragile is Africa's recent growth? Journal of African Economies 19(1): 1-24. https://doi. org/10.1093/jae/ejp017

Ayres, R.U. (1994). Information, entropy and progress: A new evolutionary paradigm. New York: American Institute of Physics.

Cilliers, P. (1998). Complexity and postmodernism: Understanding complex systems. London: Routledge.

Environmental Protection Agency - Ghana. (2019). AKOBEN programme. http:// www.epa.gov.gh/epa/projects/akoben [Accessed 20 September 2019].

International Labour Organization. (2014). Global employment trends 2014: Risk of a jobless recovery? Geneva: ILO.

International Resource Panel. (2019). Global resources outlook: Natural resources for the future we want. Nairobi: UNEP

Lindhqvist, T. (1998). What is extended producers responsibility? In: K. Jönsson \& T. Lindhqvist (Eds), Extended producer responsibility as a policy instrument: What is the knowledge in the scientific community? Lund: Lund University.

McClaughry, J. (1989). Preface. In: E.F. Schumacher, Small is beautiful. London: Harper Perennial.

McKinsey Global Institute (2010). Lions on the move: The progress and potential of African economies. https://mck.co/2qGbXhZ [Accessed 15 September 2019].
McKinsey Global Institute. (2016). Lions on the move II: Realizing the potential of Africa's economies. https://mck.co/2NfutLS [Accessed 15 September 2019].

Meadows, D., Meadows, D. \& Randers, J. (1992). Beyond the limits. London: Earthscan Publications.

Mebratu D. (2000). Strategies for sustainable industrial development in sub-Saharan Africa. Lund: Lund University.

Mosley, P., Harrigan, J. \& Tage, J. (1991). Aid and power: The World Bank and policybased lending. New York: Routledge.

Muriithi T. (2005). The African Union: PanAfricanism peace building and development. Burlington, VT: Ashgate Publishing.

Organization of African Unity, Economic Commission for Africa \& United Nations Industrial Development Organization. (1997). Report of the mid-term programme evaluation of IDDA II. Vienna: UNIDO.

Oser, J. \& Blanchfield W.C. (1975). The evolution of economic thought. New York: Harcourt Brace Jovanovich Inc.

Partnership for Action on Green Economy. (2017). Green industrial policy: Concept, policies and country experiences. Geneva: UN Environment.

Pearce, D.W. \& Turner, R.K. (1990). Economics of natural resources and the environment. New York: Harvester Wheatsheaf.

Perez C. (2010). The financial crisis and the future of innovation: A view of technical change with the aid of history. The Other Cannon Foundation \& Tallinin University of Technology Working Papers in Technology Governance and Economic Dynamics, 28, TUT Ragnar Nurkse Department of Innovation and Governance.

Radelet, S. \& Sirleaf, E. (2010). Emerging Africa: How 17 countries are leading the way. Baltimore, MD: Brookings Institution Press. 
Rasheed, S. \& Luke, D.F. (Eds). (1995). Development management in Africa: Toward dynamism, empowerment, and entrepreneurship. Boulder, CO: Westview Press. https://doi.org/10.11 $11 /$ j.1467-8268.1995.tb00076.x

Reed, D. (1992). Structural adjustment and the environment. London: Earthscan Publications.

Rifkin, J. (2011). The third industrial revolution: How lateral power is transforming energy, the economy and the world. New York: St. Martin's Griffin.

Roberts, H. \& Robinson, G. (1998). ISO 14001 EMS implementation handbook. Oxford: Butterworth-Heineman.

Robertson, C., Mhango, Y. \& Moran, M. (2012). The fastest billion: The story behind Africa's economic revolution. London: Renaissance Capital.

Rodrik, D. (2016). Premature deindustrialisation. Journal of Economic Growth 21(1): 1-33. https://bit.ly/2q06dCG [Accessed 18 September 2019]. https://doi. org/10.1007/s10887-015-9122-3

Rodrik, D. (2017). Growth without industrialisation. https://bit.ly/2OG72uP [Accessed 28 May 2019].

Roszak, T. (1989). Introduction. In: E.F. Schumacher, Small is beautiful. New York: Harper Perennial.

Schwab, K. (2018). Shaping the fourth industrial revolution. Geneva: WEF.

Stein, H. (1998). Globalisation, adjustment and the structural transformation of African economies. Chicago: Roosevelt University. https://doi.org/10.2139/ssrn.165812

United Nations. (1992). A programme for the second industrial development decade for Africa (1991-2000): Self-sustained development through industrialization. New York: United Nations.
United Nations Conference on Trade and Development. (2012). The new partnership for Africa's development: Performance, challenges, and the role of UNCTAD. Geneva: UNCTAD.

United Nations Economic Commission for Africa. (1980). Lagos plan of action. Addis Ababa: UNECA.

United Nations Economic Commission for Africa. (1991). The second United Nations transport and communications decade in Africa. Addis Ababa: UNECA.

United Nations Economic Commission for Africa. (1996). Economic and social survey of Africa. Addis Ababa: UNECA.

United Nations Economic Commission for Africa. (2015). Economic report on Africa 2015: Industrializing through trade. Addis Ababa: UNECA.

United Nations Economic Commission for Africa. (2016a). Greening Africa's industrialisation. Addis Ababa: UNECA.

United Nations Economic Commission for Africa. (2016b). Transformative industrial policy for Africa. Addis Ababa: UNECA.

United Nations Economic Commission for Africa. (2017). Urbanisation and industrialisation for Africa's transformation. Addis Ababa: UNECA.

United Nations Environment Programme. (2001). Environmental management of industrial estates in China. Nairobi: UNEP.

United Nations Environment Programme. (2002). Cleaner production: Seventh International High-level Seminar. Industry and Environment Review 25(3-4). Paris: UNEP.

United Nations Environmental Programme \& United Nations Industrial Development Organization. (2010). PRE-SME Promoting resource efficiency in small \& medium sized enterprises: Industrial training handbook. Paris: UNEP. 
United Nations Industrial Development Organization. (1982). A programme for the industrial development decade for Africa. Vienna: UNIDO.

United Nations Industrial Development Organization. (2009). Green industry for a low-carbon future. Vienna: UNIDO.

United Nations Industrial Development Organization. (2016). Global assessment of eco-industrial parks in developing and emerging countries. Vienna: UNIDO. van Weenen, J.C. (1997). Sustainable product development: Opportunities for developing countries. Industry and Environment 20(1/2): 14-20.

World Bank. (1989). Sub-Saharan Africa: From crisis to growth. Washington, DC: World Bank. 